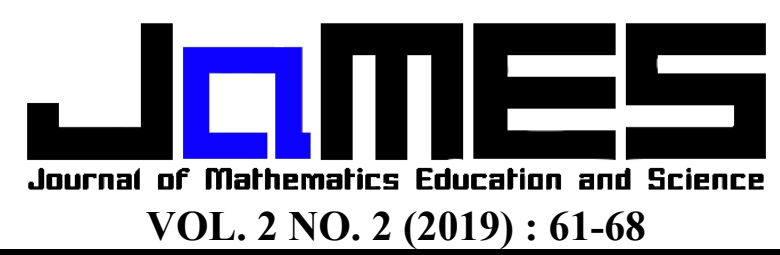

p-ISSN: 2621-1203 | https://doi.org/10.32665/james.v2i2.74

e-ISSN: 2621-1211

\title{
ETNOMATEMATIKA EKSPLORASI TAPIS LAMPUNG SEBAGAI SUMBER BELAJAR DALAM UPAYA MELINDUNGI WARISAN BUDAYA LAMPUNG
}

\author{
Fiola Cita Dewi ${ }^{1}$, Aida Nurfithriyya ${ }^{2}$, Susiana $^{3}$, Rosida Rakhmawati ${ }^{4}$, \\ Bambang Sri Anggoro 5 \\ Universitas Islam Negeri Raden Intan Lampung, fiolacitadewi06@gmail.com ${ }^{1}$ \\ Universitas Islam Negeri Raden Intan Lampung, aidanurfitria@gmail.com² \\ Universitas Islam Negeri Raden Intan Lampung, susiana1216@gmail.com ${ }^{3}$ \\ Universitas Islam Negeri Raden Intan Lampung, rosidarakhmawati@radenintan.ac.id ${ }^{4}$ \\ Universitas Islam Negeri Raden Intan Lampung, bambangsrianggoro@radenintan.ac.id ${ }^{5}$ \\ Received : 12 Februari 2019, Revised : 15 Oktober 2019, Accepted : 16 Oktober 2019, \\ (C) Mathematics Education Unugiri 2019
}

\begin{abstract}
This study aimed to find out what were the activities of ethnomathematics on the Tapis cloth that can be used as a source of mathematics learning. The data obtained are qualitative data with data sourced from observation and participant observation (fieldwork), interview and questioner, document and text, impression, and the reaction of the researcher. The technique of validity was using triangulation. The result of the research showed that from several kinds of Tapis cloths: 1) They had a philosophical sense on every Tapis motif related to the Lampung people's existence. 2) Two activities exist in Tapis Lampung that was measuring activity and counting activity. 3) Mathematical concepts on Lampung filters include One-dimensional geometry found in the star's motifs that applied the line concept. The twodimensional geometries were triangles, rhombus, and elliptical rectangles derived from Tapis Pucuk Rebung, swaying headers, stylish headlines, and geometric motifs. Transformation Geometry concept of Reflection and Rotation was on mangosteen flower and leaf flower. Dilatation was on the rhombus motif. The translation was on the motives of humans and riding animals.
\end{abstract}

\section{Keywords: Tapis, Ethnomathematics, Learning Source}

\begin{abstract}
Abstrak
Penelitian ini bertujuan untuk mengetahui apa saja aktivitas etnomatematika pada kain tapis yang dapat dijadikan sebagai sumber belajar matematika. Data yang diperoleh berupa data kualitatif dengan sumber data dari observasi dan observasi partisipan (kerja lapangan), wawancara dan kuesioner, dokumen dan teks, kesan dan reaksi peneliti. Teknik keabsahan dengan cara triangulasi. Hasil penelitian menunjukkan bahwa dari beberapa macam kain tapis : 1) Memiliki makna filosofis pada setiap motif kain tapis yang berkaitan dengan kehidupan masyarakat Lampung. 2) Terdapat dua aktivitas yang ada pada Tapis Lampung yaitu aktivitas mengukur dan aktivitas membilang. 3) Konsep matematika pada tapis Lampung meliputi : Geometri dimensi satu yaitu garis terdapat pada motif bintang. Geometri dimensi dua yaitu segitiga, persegi belah ketupat dan elips yang berasal dari tapis pucuk rebung, tajuk berayun, tajuk dipergaya dan motif geometris. Transformasi Geometri konsep Refleksi dan Rotasi pada motif bunga manggis dan bunga daun. Dilatasi pada motif Belah Ketupat. Translasi pada motif Manusia dan Hewan Tunggangan.
\end{abstract}

\section{Kata Kunci : Tapis, Etnomatematika, Sumber Belajar}

\section{Pendahuluan}

Indonesia merupakan negara yang mempunyai berbagai macam keragaman adat dan budaya. Dari berbagai Provinsi di Indonesia memiliki adat istiadat yang berbeda, yang dapat menarik perhatian para wisatawan untuk 
mengetahui berbagai adat kebudayaan yang ada. Salah satu Provinsi di Indonesia yang memilki kekayaan ragam budaya yaitu Provinsi Lampung tepatnya di Pulau Sumatra dibagian Selatan. Lampung merupakan suatu Provinsi yang dikenal akan berbagai ragam budaya seperti upacara adat, rumah adat, tarian adat, pakaian adat, bahasa dan kerajinan tradisional. Salah satu ciri khas dari Provinsi Lampung terlihat dari kerajinan tradisionalnya. Kerajinan tradisional yang ada di masyarakat Lampung salah satunya adalah kain tapis Lampung.

Kain tapis merupakan pakaian adat wanita Lampung berbentuk sarung yang dibuat menggunakan sistem sulam yang terdiri dari tenun benang kapas dengan hiasan atau motif bahan sugi, serta benang emas atau benang perak Lampung Cucuk [1]. Kain tapis yang terdapat di Provinsi Lampung memilki berbagai macam motif.

Unsur matematika yang terdapat didalam kain tapis yaitu unsur geometri. Geometri merupakan suatu bidang kajian dalam materi matematika, adapun materi geometri yang meliputi: hubungan antar garis, sudut, segitiga dan segiempat, teorema pythagoras, dan lingkaran [2]. Materi yang meliputi bidang geometri tersebut diajarkan kepada siswa SMP. Dalam pembelajaran matematika khususnya geometri setiap siswa harus memiliki keterampilan dalam mengkonsep keterampilan dalam menganalisis khususnya pada soal cerita, dapat menjelaskan keterkaitan antar konsep, serta dapat memecahkan suatu masalah yang berkaitan dengan kemampuan memahami masalah. Tetapi kenyataannya siswa sulit mengkomunikasikan ide, kesulitan menerapkan konsep, serta kesulitan dalam menganalisis terutama pada soal cerita[3]. Sehingga pada akhirnya siswa tidak dapat memecahkan masalah tersebut, dikerenakan ada beberapa faktor yang tidak dimiliki oleh siswa sebagai prasyarat untuk menyatakan persoalan dari geometri.

Berdasarkan survei PISA, prestasi belajar geometri siswa menegah Indonesia sangatlah rendah yaitu dengan rata-rata $-0,31$ dengan standar deviasi 1,12 pada tahun 2003
[4]. Hasil PISA 2012 juga menunjukkan kemampuan matematika terhadap siswa kelas SMP di Indonesia dapat dianggap rendah [5]. Selain itu hasil TIMSS 2015, Indonesia juga lemah dalam aspek konten Geometri dan aspek kognitif pada kemampuan penalaran. Lebih dari $50 \%$ siswa Indonesia ada di level sangat rendah dan 30\% siswa ada di level rendah. Persentase rata-rata yang sangat rendah dicapai oleh siswa Indonesia pada domain kognitif level penalaran (reasoning) yaitu 17\% [6].

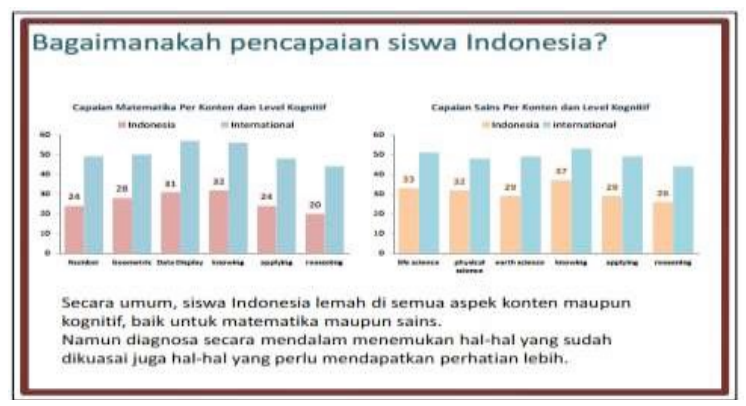

Gambar 1. Pencapaian Prestasi Indonesia

Dari gambar diatas terlihat bahwa pencapaian kemampuan penalaran siswa Indonesia mempunyai persentase yang sangat rendah dan kemampuan di konten geometri menempati urutan kedua dari tiga aspek kognitif yang diujikan [7]. Hasil PISA dan TIMSS merupakan capaian literasi matematika siswa Indonesia. Faktor dari hasil PISA dan TIMSS rendah disebabkan karena siswa Indonesia kurang berlatih dalam menyelesaikan soal-soal dengan karakteristik seperti soal-soal pada TIMSS dan PISA [8].

Pada bidang geometri, eksplorasi sumber belajar yang digunakan tidak hanya terpaku pada buku ajar tetapi juga dapat menggunakan konsep matematika yang berkaitan dengan unsur budaya. Sumber belajar merupakan segala sumber yang dimanfaatkan siswa dalam kegiatan belajar yang dapat meningkatkan kuantitas dan kualitas belajarnya [9].

Budaya yang berkaitan terhadap konsep-konsep matematika biasa disebut etnomatematika, dimana unsur-unsur budaya, tempat tinggal dapat digunakan sebagai sumber belajar [10]. Etnomatematika berasal dari kata 
ethnomathematics, yang diperkenalkan oleh D'Ambrosio salah satu matematikawan dari Brasil pada tahun 1977 [11]. Etnomatematika adalah matematika yang dipraktekkan oleh kelompok budaya, seperti halnya masyarakat perkotaan dan pedesaan, kelompok pekerja, kelas profesional, anak-anak dalam kelompok usia tertentu, masyarakat adat, dan begitu banyak kelompok lain yang diidentifikasi oleh tujuan dan tradisi yang sama [12].

Istilah etnomatematika dikemukakan oleh D'Ambrosio (1985), menggambarkan praktik matematika pada kelompok budaya yang dapat diidentifikasi serta dianggap sebagai studi ide matematika yang ditemukan dalam budaya apapun. D'Ambrosio (1990) mendefinisikan etnomatematika :"The prefix ethno is today accepted as a very broad term that refers to the socialcultural context and therefore includes language, jargon, and codes of behavior, myths, and symbols. The derivation of mathema is difficult, but tends to mean to explain, to know, to understand, and to do activities such as ciphering, measuring, classifying, inferring, and modeling. The suffix tics is derived from techné, and has the same root as technique"(p.81) [13].

Dengan kata lain, etno mengacu pada sekelompok anggota yang berada dalam lingkungan budaya yang diidentifikasi oleh tradisi budaya, kode, simbol, mitos, dan caracara khusus mereka digunakan untuk menjadi alasan dan untuk menyimpulkan [14]. Etnomatematika merupakan ilmu yang dapat digunakan serta untuk memahami bagaimana matematika diadaptasi dari sebuah budaya [15].

Budaya merupakan suatu hal yang tidak bisa dihindari dari kehidupan sehari-hari, karena budaya merupakan satu kesatuan utuh dan menyeluruh dari beragam perwujudan yang dihasilkan dan berlaku dalam sekelompok masyarakat [16]. Upaya dalam melindungi warisan budaya menggunakan Konteks budaya yaitu dengan menggunakan budaya yang ada di Propinsi Lampung itu sendiri, Lampung memiliki keragaman budaya yang khas seperti rumah adat, makanan, kerajinan tangan, transportasi, dan lain-lain. Jika dilakukan eksplorasi lebih mendalam, budaya Lampung memiliki unsur-unsur budaya serta memuat konsep-konsep matematika seperti simetri, pola bilangan dan lain-lain. Dimana hasil eksplorasi budaya tersebut dapat dijadikan sebagai sumber belajar dalam pengembangan bahan ajar matematika [17].

Berdasarkan pendahuluan yang sudah dipaparkan mengenai etnomatematika, sebagai acuan untuk melanjutkan penelitian berdasarkan temuan baru tentang konsep matematika yang ada dalam kain tapis lampung yang dapat dijadikan sebagai sumber belajar. Sehingga didapat rumusan masalahnya adalah apa sajakah aktivitas etnomatematika pada kain tapis yang dapat dijadikan sebagai sumber belajar matematika serta bertujuan untuk menggali potensi pada siswa terhadap kain tapis lampung sehingga dapat dijadikan sumber belajar matematika.

\section{Metodologi Penelitian}

Penelitian ini menggunakan penelitian kualitatif. Penelitian kualitatif adalah suatu penelitian yang ditunjukan untuk menggambarkan serta menganalisis fenomena, pristiwa, aktivitas sosial, sikap, kepercayaan persepsi, serta pemikiran orang secara individual atau kelompok [18]. Penelitian kualitatif dalam ilmu sosial yang dikembangkan untuk memungkinkan peneliti mempelajari fenomena sosial dan budaya. Contoh metode kualitatif adalah penelitian tindakan, penelitian studi kasus dan etnografi. Sumber data kualitatif berupa observasi dan observasi partisipan (kerja lapangan), wawancara dan kuesioner, dokumen dan teks, dan kesan dan reaksi peneliti [19].

Pendekatan yang akan dilakukan menggunakan pendekataan etnografi. Penelitian etnografi bertujuan untuk mendeskripsikan dan menganalisis budaya berdasarkan penelitian lapangan yang intensif. Teknik analisis data yang digunakan yaitu menggunakan model spradley, seperti pada Gambar 2.

Analisis data dilakukan dalam 2 (dua) tahap, yaitu analisis data saat berada dilapangan dan analisis data setelah data terkumpul. 
Analisis data dikerjakan selama pengumpulan data berlangsung hingga penyusunan laporan selesai. Sebagai langkah awal, data yang merupakan hasil wawancara dengan informan kunci (key informan) dipilih dan diberi kode berdasarkan kesamaan isu, tema dan masalah yang ada didalamnya dengan terus mencari data-data baru. Sedangkan analisis data setelah terkumpul atau data yang baru diperoleh setelah pelaksanaan pengumpulan data, maka dianalisis dengan membandingkannya dengan data yang terdahulu.

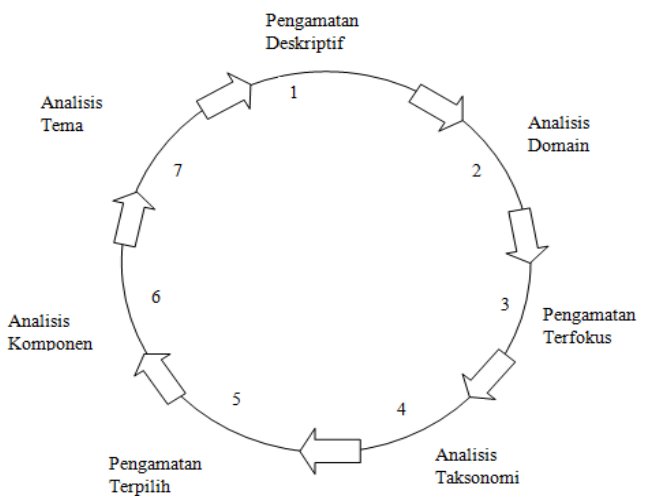

Gambar 2. Proses Penelitian dan Analisis Data

\section{Hasil dan Pembahasan}

Berdasarkan hasil wawancara kepada empat narasumber yang menjadi subjek penelitian yaitu Bapak Raswan pemilik toko kain tapis sebagai subjek satu, Ibu Eko Wahyuningsih selaku pamong budaya museum negeri Lampung sebagai subjek dua, Bapak Banon Eko Susetyo selaku budayawan Lampung sebagai subjek tiga dan Bapak Azhari Kadir selaku budayawan Lampung sebagai subjek empat. Dapat diambil kesimpulan dari tringulasi keempat narasumber yaitu makna yang terdapat pada setiap motif kain tapis lampung, juga dalam pengukuran motif kain tapis lampung dengan pengulangan pola konsep awal kesimetrisan dan beberapa konsep kajian geometri.

Beberapa macam kain tapis yang akan diambil peneliti untuk diteliti antara lain Tapis: Jung Sarat, Kaca, Gajah Meghem dan Raja Tunggal. Dari setiap jenis tapis tersebut akan dikaji tentang makna filosofis serta keterkaitannya dengan indicator etnomatematika yakni aktivitas membilang, aktivitas mengukur, beberapa aspek geometris dan transformasi geometri. Kain tapis mempunyai beberapa aktivitas etnomatematika yaitu :

\subsection{Aktivitas Mengukur}

Aktivitas mengukur adalah suatu aktivitas yang terkaji dalam etnomatematika. Pada aktivitas mengukur digunakan suatu ukuran baku. Dalam proses pengukuran kain tapis tidak menggunakan ukuran baku karena konsep matematika belum diterapkan pada masyarakat dahulu. Meskipun Masyarakat jaman dahulu tidak menggunakan satuan ukur yang baku dan belum mengenal istilah geometri, namun berbagai motif tersebut menerapkan aktivitas mengukur yang menghasilkan pola bilangan serta berbagai motif yang simetris.

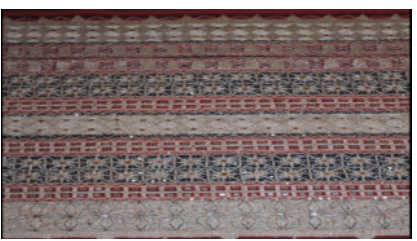

Gambar 3. Tapis Kaca

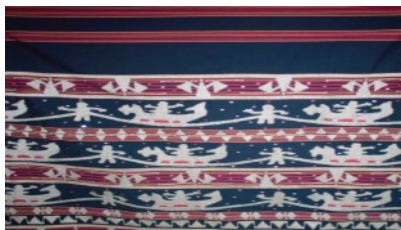

Gambar 4. Tapis Raja Tunggal

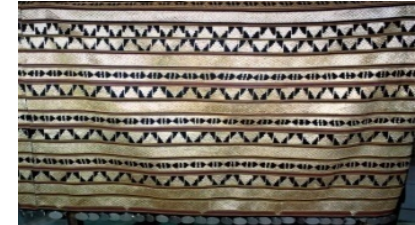

Gambar 5. Tapis Jung Sarat

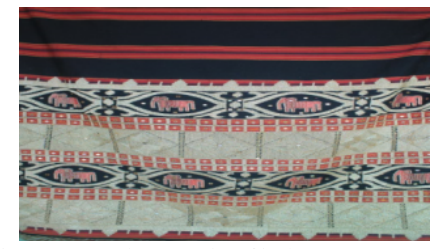

Gambar 6. Tapis Gajah Meghem

Terdapat empat jenis kain tapis akan diukur menggunakan satuan ukuran baku. Tapis 
kaca membutuhkan bahan dasar dengan panjang $140 \mathrm{~cm}$, lebar $72 \mathrm{~cm}$ dengan 900 gram berat benang emas, tapis raja tunggal membutuhkan bahan dasar dengan panjang 112 $\mathrm{cm}$, lebar $64,5 \mathrm{~cm}$ dengan 500 gram berat benang emas, tapis jung sarat membutuhkan bahan dasar dengan panjang $110 \mathrm{~cm}$, lebar 64 $\mathrm{cm}$ dengan 1000 gram berat benang emas, pembuatan tapis gajah meghem membutuhkan bahan dasar dengan panjang $130 \mathrm{~cm}$, lebar 80 cm dengan 500 gram berat benang emas. Pada motif kain tapis juga membentuk suatu pola bilangan yang sesuai dengan kesimetrian dalam matematika.

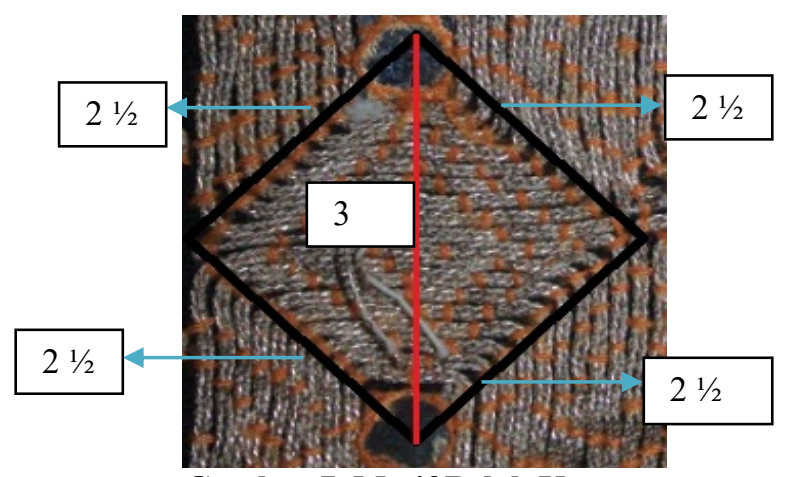

Gambar 7. Motif Belah Ketupat

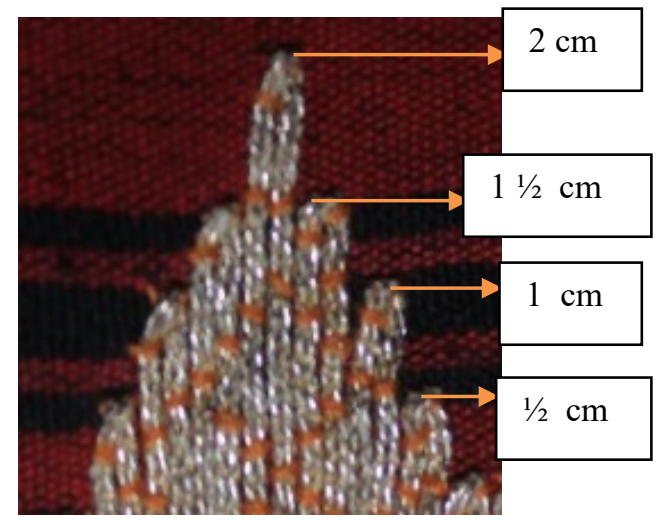

Gambar 8. Motif Pucuk Rebung

\subsection{Aktivitas Membilang}

Berdasarkan empat jenis tapis yag diteliti terdapat aktivitas membilang disetiap pembuatannya menggunakan benang emas rangkap 4, 5, 6, 7 atau 8. Dan pola-pola dari tapis tersebut dapat menggunakan aktivitas membilang yaitu sai (satu), rhua (dua), telu (tiga), epak (empat), lima (lima), enom (enam), pitu (tujuh), walu (delapan).

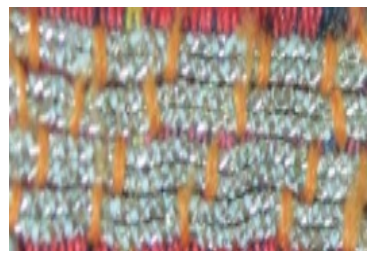

Gambar 9. Benang emas rangkap empat (Epak)

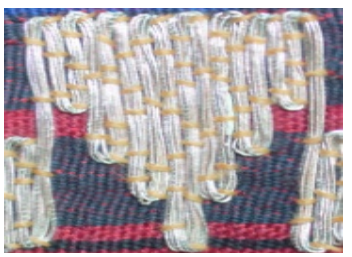

Gambar 10. Benang emas rangkap delapan (Walu)

Gambar tersebut merupakan contoh dari motif kain tapis dengan pola bilangan dalam proses sulam benang emas.

\subsection{Bentuk Geometri}

Konsep geometri erat kaitannya dengan peninggalan sejarah termasuk kain tapis. Jika dilihat dari motif kain tapis terdapat hubungan erat dari setiap motif yang saling berhubungan dan berkaitan dengan konsep geometri. Garis merupakan salah satu konsep geometri yaitu geometri dimensi satu.

Gambar dibawah ini merupakan motif bintang mempunyai makna bahwa sebagai manusia harus saling menghormati dan saling menginspirasi satu dengan yang lainnya. Makna garis lurus yang terdapat pada motif bintang ini adalah sebagai kekuatan, arah dan perlawanan. Terdapat pula garis tegak lurus, garis berpotongan, garis sejajar dan sudut dalam motif bintang yang memiliki makna tersendiri.

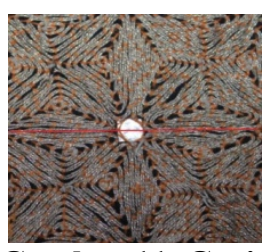

Gambar 11. Garis Horizontal

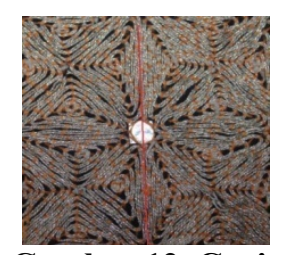

Gambar 12. Garis Vertikal 


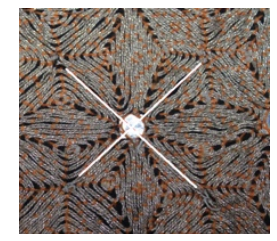

Gambar 13. Garis Berpotongan

sendiri mela garis vertikal dengan horizontal mencerminkan aturan-aturan adat, nilai sosial, agama dan hubungan baik antar masyarakat. Garis yang berpotongan bermakna sebagai pagar yang melindungi rumah tinggal dari gangguan luar.

Motif kain tapis juga terdapat konsep geometri dimensi dua yaitu segitiga, persegi belah ketupat dan elips yang berasal dari tapis pucuk rebung, tajuk berayun, tajuk dipergaya dan motif geometris. Pada seni dan arsitektur Islam, geometri telah diberlakukan sejak awal dan sebagai bentuk penolakan Islam terhadap gambar-gambar figuratif dan pagan yang dapat memicu berhala.

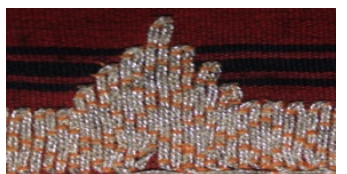

Gambar 14. Motif

Pucuk Rebung Tapis Gajah Meghem

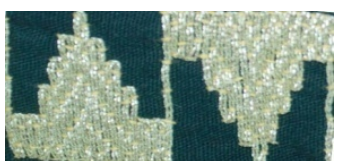

Gambar 16. Motif

Tajuk Berayun Tapis Raja Tunggal

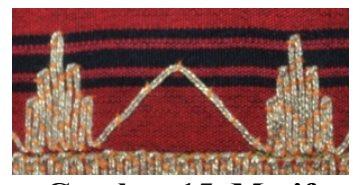

Gambar 15. Motif Tajuk Berayun Tapis Kaca

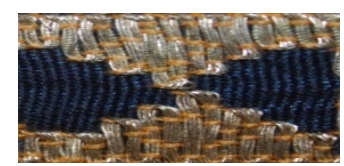

Gambar 17. Motif

Tajuk Dipergaya Tapis Jung Sarat
Motif pucuk rebung memiliki makna hubungan keluarga yang tidak dapat dipisahkan untuk saling tolong menolong serta saling menjaga silaturahmi. Motif tajuk berayun memiliki makna teguh pendirian pada sesuatu yang sudah disepakati agar tidak terpengaruh pada hal-hal negatif dalam setiap perkembangan zaman. Sedangkan motif tajuk dipergaya memiliki makna bahwa kita sebagai manusia harus mampu menyesuaikan diri dalam lingkungan agar harga diri tetap terjaga. Contoh pola segitiga pada motif pucuk rebung seperti gambar berikut :

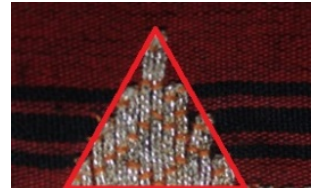

Gambar 18. Segitiga

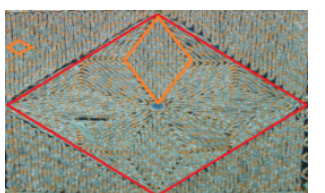

Gambar 20. Belah Ketupat
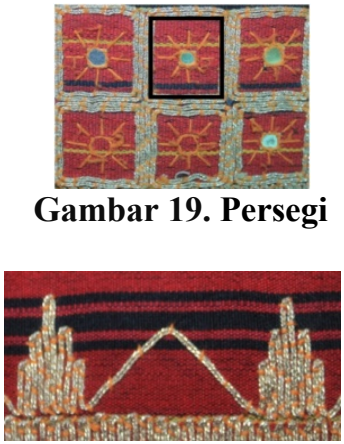

Gambar 21. Motif Pohon Hayat
Pada Gambar 18, bangun segitiga pada motif pucuk rebung diatas adalah segitiga sama sisi (equilateral triangle). Segitiga sama sisi juga termasuk segitiga sama kaki. "Pada suatu segitiga sama kaki kedua sudut alasnya sama besar"

Pada Gambar 19, motif kain tapis di atas berbentuk persegi yang jika dilihat makna filosofinyaberarti suatu lembaga akan sempurna jika didukung oleh pihak yang memiliki keahlian menurut bidangnya. Sedangkan menurut ilmu matematika persegi merupakan poligon yang meiliki empat sisi. Motif persegi terdapat pada tapis gajah meghem dan kaca.

Pada Gambar 20, merupakan motif belah ketupat, yang bermakna filosofis untuk menjalin silaturahmi antar sesama dengan mempertahankan tingkah laku serta berbuat kebaikan serta selalu berbagi. Sedangkan menurut konsep matematika belah ketupat merupakan suatu jajar genjang yang memiliki panjang sisi yang sama besar.

Pada Gambar 21, motif diatas merupakan motif labang hayat yang melambangkan seseorang dalam menentukan jalan hidupnya. Pohon hayat yaitu sumber kekayaan serta kemakmuran. Sedangkan menurut ilmu matematika motif tersebut berbentuk elips. Elips adalah gambar yang menyerupai lingkaran yang kemudian dipanjangkan ke suatu arah.

\subsection{Transformasi Geometri}

http://journal.unugiri.ac.id/index.php?journal=JaMES 
Dalam konsep matematika transformasi geometri merupakan suatu pemetaan titik pada suatu bidang ke himpunan titik pada bidang yang sama. Jenis-jenis dari transformasi yang dapat dilakukan diantaranya : Refleksi, Translasi, Rotasi dan Dilatasi. Terdapat konsep transformasi geometri dalam motif bunga manggis pada tapis kaca dan motif bunga daun pada motif gajah meghem.

\subsubsection{Refleksi}

Gambar dibawah ini menunjukkan motif bunga daun yang dipotong menggunakan sumbu- $\mathrm{X}$ dan sumbu- Y. sifat refleksi yang diterapkan pada motif bunga daun yakni Refleksi terhadap sumbu- X, Sumbu- Y dan refleksi pada titik $\mathrm{O}(0,0)$.
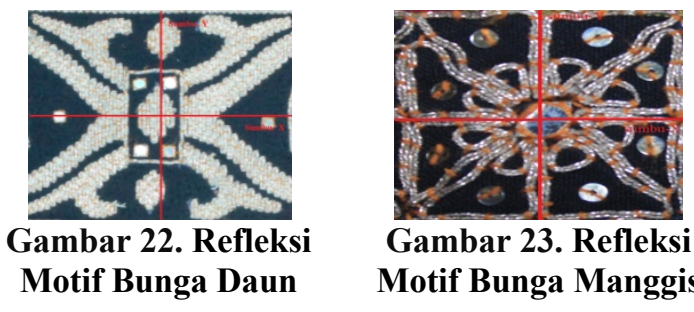

Gambar 23. Refleksi

Motif Bunga Manggis

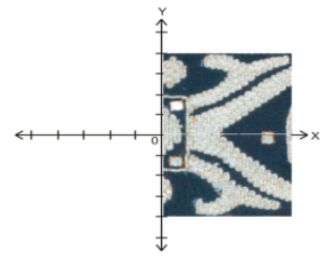

Gambar 24.

Pencerminan SumbuY Motif Bunga Daun

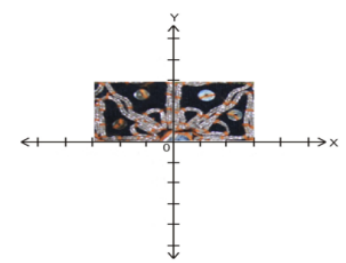

Gambar 25.

Pencerminan Sumbu-X Motif Bunga Manggis

\subsubsection{Rotasi}

Rotasi adalah memutar titik pada setiap bidang dengan menggunakan titik pusat tertentu yang memiliki jarak sama dengan setiap titik yang diputar (jari-jari).

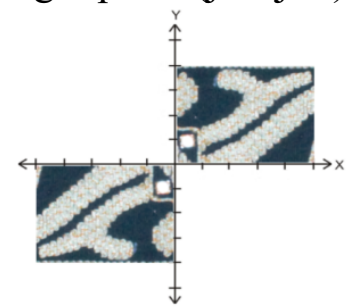

Gambar 26.

Pencerminan

Terhadap Titik $\mathbf{O}(0,0)$ Motif Daun

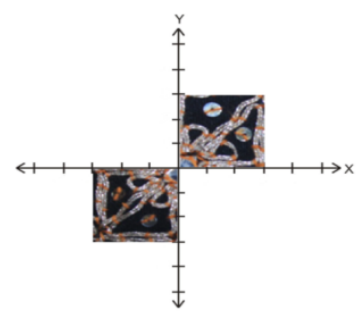

Gambar 27.

Pencerminan Terhadap Titik O(0,0) Motif Bunga Manggis

\subsubsection{Dilatasi}

Dilatasi merupakan bentuk pembesaran atau pengecilan pada transformasi.

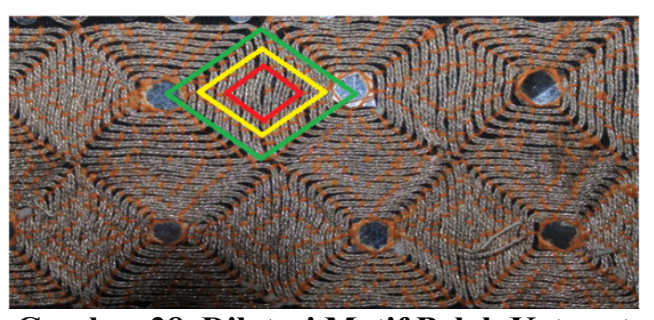

Gambar 28. Dilatasi Motif Belah Ketupat

\subsubsection{Translasi}

Translasi atau pergeseran adalah transformasi yang memindahkan titik pada setiap bidang menurut jarak dan arah tertentu, translasi hanya memindahkan tanpa mengubah ukuran tanpa memutar. Motif hewan tunggangan pada tapis raja tunggal menerapkan konsep translasi.

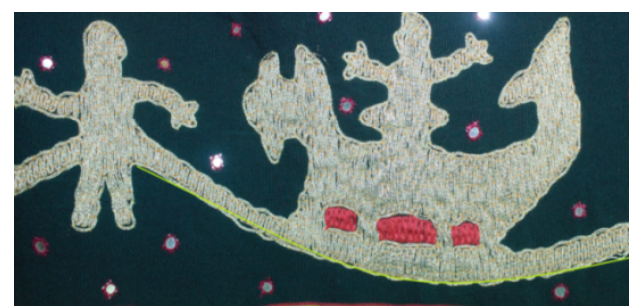

Gambar 29. Motif Manusia dan Hewan Tunggangan

Motif manusia (penyimbang) sedang duduk di atas hewan tunggangan yang ditarik oleh manusia (beduwow) mengandung makna bahwa pemimpin (penyimbang) harus memiliki yang hati bersih untuk menjadi pemimpin yang baik dari beduwow.

\section{Penutup}

Berdasarkan dari yang telah dijelaskan sebelumnya dapat ditarik kesimpulan bahwa didalam budaya lampung terdapat banyak sekali ragam budaya serta adat istiadat di masyarakat lampung. Aktivitas etnomatematika yang terdapat dalam kain tapis lampung memiliki dua aktivitas yaitu aktivitas mengukur dan aktivitas membilang. Pada motif kain tapis juga membentuk suatu pola bilangan yang sesuai dengan kesimetrian dalam matematika. Sedangkan konsep matematika yang ada dalam 
motif kain tapis lampung merupakan eksplorasi dari etnomatematika.

\section{Referensi}

[1] Pemerintah Provinsi Lampung Dinas Pendidikan dan Kebudayaan, Katalog Kain Tapis (Koleksi Museum Negeri Provinsi Lampung "Ruwa Jurai". Lampung, (2015).

[2] Muhassanah, N., I. Sujadi, dan R. Riyadi, "Analisis Keterampilan Geometri Siswa Dalam Memecahkan Masalah Geometri Berdasarkan Tingkat Berpikir Van Hiele," J. Pembelajaran Mat., vol. 2, no. 1 (2014).

[3] Yuwono, M. R., "Analisis kesulitan mahasiswa dalam menyelesaikan soal geometri berdasarkan taksonomi bloom dan alternatif pemecahannya," Beta J. Tadris Mat., vol. 9, no. 2,(2016) 111-133,

[4] Stacey, K., "The PISA view of mathematical literacy in Indonesia," $J$. Math. Educ., vol. 2, no. 2 (2011) 95-126,

[5] Murdaningsih, S. dan B. Murtiyasa, "An Analysis on Eight Grade Mathematics Textbook of New Indonesian Curriculum (K-13) Based on Pisa's Framework," JRAMathEdu J. Res. Adv. Math. Educ., vol. 1, no. 1 (2016) 14-27.

[6] Sari, E. F. P., S. Somakim, dan Y. Hartono, "Etnomatematika pada Kebudayaan Rumah Adat Ogan Komering Ulu Sumatera Selatan," J. Medives, vol. 2, no. 1 (2018) 137-144,.

[7] Pribadi, A., S. Somakim, dan M. Yusup, "Pengembangan Soal Penalaran Model Timss Pada Materi Geometri Dan Pengukuran SMP," HISTOGRAM J. Pendidik. Mat., vol. 1, no. 2 (2018) 115128.

[8] Sriyatun, S., M. Masrukan, dan W. Wardono, "Analisis Literasi Matematika Pada Pembelajaran Kuantum Metode Mind Mapping Berbantuan Schoology Berdasarkan Minat," dalam PRISMA, Prosiding Seminar Nasional Matematika, vol. 1 (2018) 145-154.
[9] Abdullah, R., "Pembelajaran berbasis pemanfaatan sumber belajar," J. Ilm. Didakt., vol. 12, no. 2(2012).

[10] Abdullah, D. I., Z. Mastur, dan H. Sutarto, "Keefektifan Model Pembelajaran Problem Based Learning Bernuansa Etnomatematika Terhadap Kemampuan Pemecahan Masalah Siswa Kelas VIII," Unnes J. Math. Educ., vol. 4, no. 3 (2015).

[11] Putri, L. I., "Eksplorasi Etnomatematika Kesenian Rebana Sebagai Sumber Belajar Matematika Pada Jenjang Mi," J. Pendas, vol. 4, no. 1 (2017).

[12] D'Ambrosio, U., Ethnomathematics: Link between traditions and modernity. Rotterdam: Sense Publisher, (2006).

[13] Rosa, M. dan D. Clark Orey, "Ethnomathematics: the cultural aspects of mathematics," Rev. Latinoam. Etnomatemática, vol. 4, no. 2 (2011).

[14] Rakhmawati, R., "Aktivitas Matematika Berbasis Budaya pada Masyarakat Lampung," Al-Jabar J. Pendidik. Mat., vol. 7, no. 2 (2016) 221-230.

[15] Marsigit, N. M. M. dan I. Rizkianto, "Pengembangan Perangkat Pembelajaran Etnomatematika Untuk Meningkatkan Kompetensi Mahasiswa Pendidikan Matematika." Jurdikmat UNY.

[16] Didik, P. L. K. P. dan P. M. G. B. B. Jambi, "Artikel Ilmiah."

[17] Wahyudi, T., "Pengembangan Soal Penalaran Tipe TIMSS Menggunakan Konteks Budaya Lampung," J. Didakt. Mat., vol. 3, no. 1 (2016).

[18] Bachri, B. S., "Meyakinkan validitas data melalui triangulasi pada penelitian kualitatif," J. Teknol. Pendidik., vol. 10, no. 1, (2010) 46-62.

[19] Myers, M. D., "Qualitative research in information systems," Manag. Inf. Syst. $Q$. , vol. 21, no. 2 (1997) 241-242. 